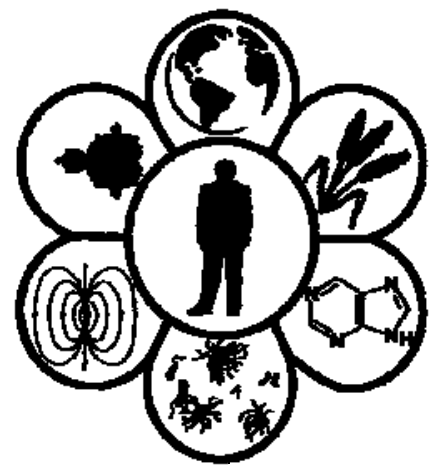

Вісник Дніпропетровського університету. Біологія, медицина Vìsnik Dnìpropetrovs'kogo unìversitetu. Serìa Bìologîa, medicina Visnyk of Dnipropetrovsk University. Biology, medicine

Vìsn. Dnìpropetr. Unìv. Ser. Bìol. Med. 2014. 5(1), 54-57. doi: $10.15421 / 021411$

ISSN 2310-4155 print ISSN 2312-7295 online www.medicine.dp.ua

\title{
Активність матриксних металопротеїназ ММП2 та ММП9 у пацієнтів з місло- та лімфопроліферативними захворюваннями
}

\author{
Ю.А. Гордієнко \\ Д3 «Дніпропетровська державна медична академія МОЗ Украӥни», Дніпропетровськ, Украӥна
}

Досліджено активність матриксних металопротеїназ ММП2 та ММП9 у плазмі крові пацієнтів з мієло- та лімфопроліферативними захворюваннями до та після хіміотерапії антрацикліновими антибіотиками даунорубіцином і адрибластином. У хворих із гострим мієлолейкозом до початку терапії активність проММП9 була суттєво зниженою (0,03 $\pm 0,01$ ум. од.), втім після хіміотерапії цей показник зростав майже в 7 разів. Хронічний лімфолейкоз і множинна мієлома супроводжуються значним підвищенням ММП9. Застосування даунорубіцину викликає зменшення активності проММП9 до 0,25 $\pm 0,10$ ум. од. у хворих на хронічний лімфолейкоз. При множинній мієломі активність проММП9 істотно знижується (у 16 разів), а ММП9 - підвищується. Співвідношення проММП9/ММП9 можна застосовувати як додатковий критерій моніторингу та ефективності хіміотерапії проліферативних захворювань крові.

Ключові слова: матриксні металопротеїнази; ММП2; ММП9; гострий мієлолейкоз; хронічний лімфолейкоз; множинна мієлома; антрациклінові антибіотики

\section{Activity of MMP2 and MMP9 matrix metalloproteinases in patients with myeloproliferative and lymphoproliferative diseases}

\author{
I.A. Gordiienko \\ State Enterprise "Dnipropetrovsk Medical Academy of the Ministry of Health of Ukraine”, Dnipropetrovsk, Ukraine
}

MMP2 and MMP9 matrix metalloproteinases due to their ability to destroy basement membranes collagen and remodeling extracellular matrix $(E C M)$ in the micro-environment of blood progenitor cells in the bone marrow play the important role in hematopoiesis. Displacement of normal hematopoiesis and dissemination of malignant cells in proliferative diseases of blood is also accompanied by catalytic ECM rearrangement. However, it is not known exactly how activity of MMP2 and MMP9 changes in various forms of leukemia and how it is affected by chemotherapeutic drugs. The aim of this study was to determine the influence of anthracycline antibiotics (daunorubicin and adriablastin) on MMP2 and MMP9 activity in blood plasma of patients with acute myeloid leukemia, chronic lymphocytic leukemia and multiple myeloma. It was established that proMMP9 activity was significantly reduced $(0,03 \pm 0,01$ rel. u.) in patients with acute myeloid leukemia before the treatment, however, after chemotherapy, it increased approximately 7 times. Chronic lymphocytic leukemia and multiple myeloma were accompanied by significant increase of MMP9 activity. Application of daunorubicin led to decrease of proMMP9 activity $(0,25 \pm 0,10$ rel. u. $)$ in patients with chronic lymphocytic leukemia. ProMMP9 activity was significantly reduced (16 times) and that of MMP9 increased in case of multiple myeloma. In studying of MMP2 activity it did not significantly change. The conclusion is that the ratio of proMMP9/MMP9 can be used as the additional criterion for monitoring the effectiveness of chemotherapy of proliferative diseases of blood.

Keywords: MMP2 and MMP9 matrix metalloproteinases; acute myeloid leukemia; chronic lymphocytic leukemia; multiple myeloma; anthracycline antibiotics

Д3 «Дніпропетровська державна медична академія МОЗ України», пл. Дзержинського, 9, Дніпропетровськ, 49044, Україна. SE “Dnipropetrovsk Medical Academy of the Ministry of Healthcare of Ukraine”, pl. Dzerzhinskiy, 9, Dnipropetrovsk, 49044, Ukraine. Tel.: +38-050-046-82-87.E-mail: gordienko.ju@gmail.com 


\section{Вступ}

Лейкози відносять до злоякісних новоутворень кровотвірної тканини з первинною локалізацією в кістковому мозку. Цілковита невиліковність даних захворювань на сучасному рівні розвитку медицини - причина більш ретельного дослідження їх патогенезу. Мієло- та лімфопроліферативні захворювання, як і будь-які неопластичні процеси, супроводжуються модифікацією екстраклітинного матриксу шляхом надмірного руйнування його складових, сприяючи дисемінації злоякісних клітин 3 кісткового мозку через периферичну кров до інших органів і тканин. Однак здатність клітин крові до міграціїïx основна фізіологічна характеристика. Ключовими ферментами, що забезпечують цей процес у нормальних i патологічних умовах, $є$ матриксні металопротеїнази (ММП) - схожі за доменною організацією цинкові кальційзалежні ендопептидази, поділені за субстратною специфічністю на колагенази, стромелізини, желатинази, мембранозв'язані ММП та ММП, що не увійшли до перелічених груп. Особливу увагу приділяють субродині желатиназ, що включає желатинази А і В (ММП2 та ММП9 відповідно), оскільки саме ці ензими здатні руйнувати колаген IV типу, що $є$ основним компонентом базальних мембран, адже саме подолання цієї перепони $\epsilon$ важливим етапом в інвазії та метастазуванні.

Для лікування онкогематологічних захворювань найчастіше застосовують антрациклінові антибіотики, незважаючи на їх виражену токсичність, яка проявляється ураженням різних органів, насамперед, серця, печінки, нирок. Для ефективної профілактики та усунення небажаних ефектів треба враховувати патогенетичні механізми, які лежать в їх основі. Серед них розглядають перекисне окиснення ліпідів, порушення метаболізму жирних кислот, функцій мітохондрій, синтезу оксиду азоту тощо (Baklanova and Ushakova, 2013). Однак нині залишається невизначеним питання, як в умовах застосування цих препаратів змінюється активність желатиназ.

Мета роботи - виявити вплив препаратів антрациклінового ряду на активність ММП2 та ММП9 у хворих iз гострим мієлолейкозом, хронічним лімфолейкозом і множинною мієломою.

\section{Матеріал і методи досліджень}

Усіх пацієнтів поділено на групи залежно від клінічного діагнозу: 1 - група пацієнтів із гострим мієлолейкозом (ГМЛ, $n=10), 2$ - хворі на хронічний лімфолейкоз (ХЛЛ, $n=7), 3$ - хворі на множинну мієлому (MМ, $n=$ 8). Групу контролю склали клінічно здорові донори $(n=$ 20). Середній вік пацієнтів усіх досліджуваних груп становив $56,1 \pm 4,3$ роки. Хворі першої та другої груп отримували даунорубіцин, а третьої - адрибластин. Усім пацієнтам уводили відповідні антибіотики внутрішньовенно з 30-40-хвилинною інфузією залежно від віку та площі поверхні тіла в дозі 45-60 мг/м²/добу впродовж трьох діб. Усі маніпуляції проведено згідно з існуючими стандартами (Vygovs'ka et al., 2002). Для дослідження використовували цитратну плазму пацієнтів, яку отри- мували до лікування та на четверту добу після курсу хіміотерапії. Активність досліджуваних ММП визначали методом желатин-зимографії з попереднім вертикальним електрофорезом зразків у 7,5\% ПААГ за присутності $0,1 \%$ ДСН та $1 \%$ желатину (Sigma, США). Після закінчення електрофорезу гель промивали у розчині Тритон X-100 та інкубували за $+37{ }^{\circ} \mathrm{C}$ протягом 16 годин у ензимному буфері, після чого гелі фарбували за кімнатної температури Кумассі діамантовим синім G250, розчиненим у суміші «метанол : оцтова кислота : вода» у співвідношенні $2,5: 1,0: 6,5$. На зимограмах дія желатиназ проявлялась як висвітлені зони на синьому фоні. Відповідність зон лізису ММП2 та ММП9 оцінювали за допомогою маркерів Bio-Rad Lab (США) і позитивного контролю на ці ензими (Sigma, США).

Зимограми переводили у цифровий формат. Обробку результатів проводили за допомогою програми Videodensitometer Sorbfil 2.0. Активність желатиназ визначали в умовних одиницях (ум. од.) відносно активності цих ферментів у стандартному зразку, в якому цей показник був прийнятий за 1 ум. од. Як стандарт використовували пул плазми крові групи здорових донорів.

Статистичну обробку результатів проводили за допомогою програм Statwin та Excel, використовуючи $t$-критерій Стьюдента та непараметричний критерій Манна - Уітні (U-критерій). Вірогідними вважали відмінності між результатами, якщо $P<0,05$.

\section{Результати та їх обговорення}

В усіх досліджуваних групах основні зміни торкались активності ММП9 та іiі зимогену. У пацієнтів першої групи до лікування виявлено різке зменшення активності проММП9 відносно контролю (рис. 1). Як відомо, саме проММП9 - основний маркер зрілих циркулюючих нейтрофілів (Bouchet and Bauvois, 2014), а для перебігу ГМЛ характерна маніфестація незрілих бластних клітин, які втратили здатність до диференціації, 3 кісткового мозку у периферичну кров. У цих неповноцінних клітинах синтез ММП9 значно знижується, але повністю не припиняється (Gajdamaka et al., 2009). 3 іншого боку, ММП9 - критичний фактор неоангіогенезу. Літературні дані свідчать, що за ГМЛ щільність судин у кістковому мозку значно збільшується (Fu et al., 2010), тобто джерелом даного ферменту можуть виступати і нелейкемічні клітини кісткового мозку - стромальні та ендотеліальні клітини, фібробласти (Klein et al., 2004).

На фоні призначення даунорубіцину у пацієнтів цієї групи вірогідно підвищувалась активність обох форм ММП9 порівняно з аналогічними показниками до хіміотерапії. Найвиразнішими виявились зміни активності проММП9, яка зростала у 7 разів, у той час як зріла форма ММП9 підвищувалась лише у 1,8 раза. Отримані дані можна пояснити так. Активація НАД(Ф)Н-оксидази під впливом антрациклінових антибіотиків зумовлює генерацію великої кількості активних форм кисню та посилення активності редоксчутливих факторів транскрипції NF-кB, AP1 та експресії прозапальних цитокінів (інтерлейкіну ІЛ6), що сприяє активації ММП9 (Spallarossa et al., 2006; Mittelstadt and Pate, 2012). 


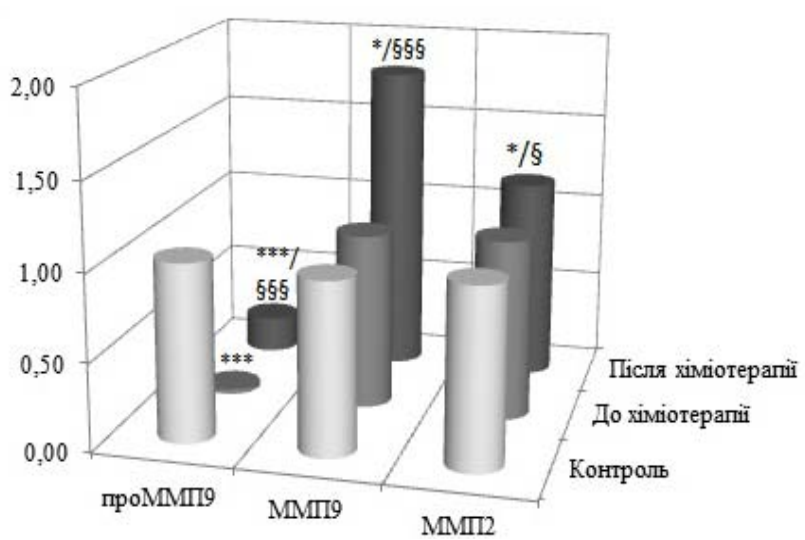

Рис. 1. Активність ММП2 та ММП9 у плазмі крові паціснтів із гострим міслолейкозом до та після хіміотерапії даунорубіцином:

$*-P<0,05, * *-P<0,01, * * *-P<0,001$ відносно контрольної групи, $\S-P<0,05, \S \S-P<0,01$,

$\S \S \S P<0,001$ відносно групи до хіміотерапії

На тлі застосування даунорубіцину у хворих цієі групи у 1,2 раза зростала активність ММП2.

У другій групі до хіміотерапії спостерігалось вірогідне (майже у 1,3 раза) підвищення ММП9 (рис. 2), яке можна пов'язати з тим, що трансформовані В-лімфоцити синтезують велику кількість проММП9 за сприяння ендотеліального фактора росту судин, фактора росту фібробластів $\beta$ (ФРФ $\beta)$, фактора некрозу пухлин $\alpha$ $(Ф Н П \alpha)$, накопичуючи, таким чином, певний пул зимогену (Yu and Han, 2006). Після застосування даунорубіцину у хворих із ХЛЛ спостерігалось пригнічення активності латентної ММП9 у 4,1 раза та зменшення ММП2 на $15 \%$.

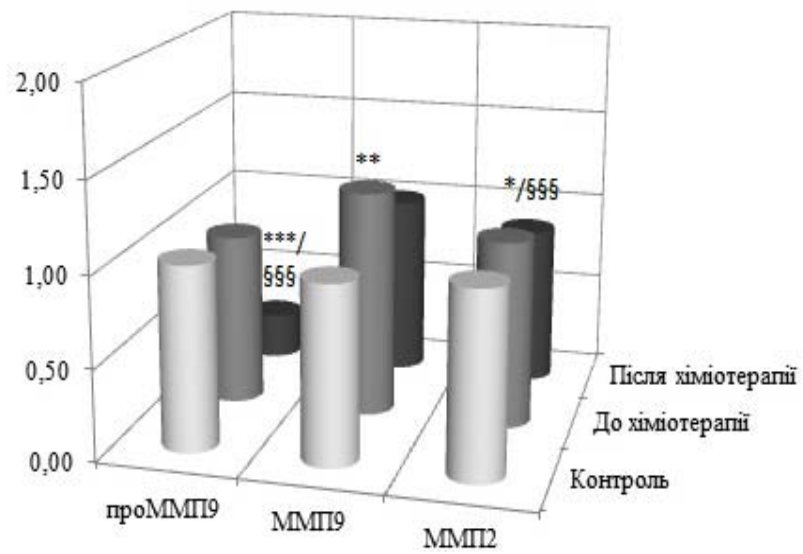

Рис. 2. Активність ММП2 та ММП9 у плазмі крові паціснтів із хронічним лімфолейкозом до та після хіміотерапії даунорубіцином: позначення див. рис. 1

Інші зміни активності желатиназ спостерігались у пацієнтів третьої групи. У ході роботи встановлено, що активність проММП9 у хворих на мієлому до лікування майже у 2,8 раза перевищувала нормальні значення, а активність ММП9 підвищувалась у 1,5 раза (рис. 3).

Означені зміни відповідають даним інших дослідників. Посилення експресії ММП9 мієломними клітинами та остеокластами стимулюється фактором росту гепатоцитів (HGF) та сигнальним трансдуктором і активатором транскрипції 3 (STAT3) (Kannaiyan, 2012). Мієломні клітини також здатні до експресії інтегрину $\alpha v \beta 3$, зв'язування якого з фібронектином і вітронектином теж викликає стимуляцію експресії MMП9 (Van Valckenborgh, 2004).

$\mathrm{У}$ разі застосування адрибластину у хворих із $\mathrm{MM}$ спостерігалось різке падіння активності проММП9 (у 16 разів). Імовірно, це можна пояснити специфікою дії антрациклінових антибіотиків, які, порушуючи синтез ДНК та РНК, перешкоджають синтезу білків. Активність ММП9, навпаки, вірогідно підвищувалась майже на $30 \%$.

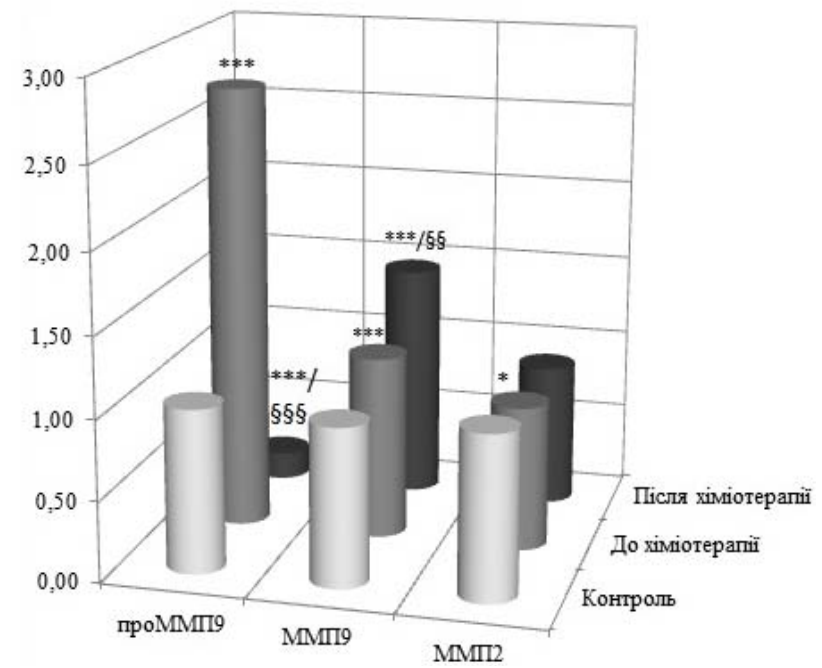

Рис. 3. Активність ММП2 та ММП9 у плазмі крові пацієнтів із множинною місломою до та після хіміотерапії адрибластином: позначення див. рис. 1

Одним із критеріїв успішної відповіді на хіміотерапію $є$ цитоліз, який оцінюють за рівнем лейкоцитів i тромбоцитів у периферичній крові. Тобто у разі застосування антрациклінових антибіотиків задля лікування будь-якого лейкозу після курсу терапії відбувається часткова або повна ерадикація злоякісного клону клітин із тимчасовим пригніченням гемопоезу, що супроводжується перебудовою екстраклітинного матриксу кісткового мозку. ММП9 - ключовий ензим, залучений до перелічених процесів. У цих умовах посилення активності ММП9 може бути свідченням відновлення мієлопоезу в кістковому мозку (Vadhan-Raj et al., 2005). Цитотоксичність антрациклінових антибіотиків проявляється також відносно інших органів і тканин, які теж сприяють підвищенню активності ММП9 у крові.

У ході дослідження виявлено виразні зміни у співвідношенні проММП9/ММП9 під час дослідження плазми пацієнтів із різними варіантами лейкозів до та після терапії. У здорових донорів цей показник становив 1,03. До лікування в групі з ГМЛ співвідношення було найменшим (0,03), після закінчення циклу хіміотерапії цей показник підвищувався учетверо $(0,12)$. У групі з ХЛЛ спостерігали проміжні зміни порівняно з іншими групами: перед початком лікування співвідношення проММП9/ММП9 у хворих цієї групи становило 0,76, після - знижувалось утричі. При ММ, навпаки, до введення адрибластину означений показник був вищим за норму у 2,4 раза, тоді як після хіміотерапії спостерігалось різке зменшення до 0,12 . 


\section{Висновки}

Активність ММП9 та ії зимогену є визначною як для первісно встановленого діагнозу (до хіміотерапії), так і після лікування. Зміни активності ММП9 залежать від типу злоякісного захворювання крові. Визначення співвідношення проММП9/ММП9 може бути додатковим критерієм моніторингу та ефективності хіміотерапії проліферативних захворювань крові.

\section{Бібліографічні посилання}

Baklanova, J.V., Ushakova, G.O., 2013. Toksychni efekty ta biohimichnyj kontrol' naslidkiv antracyklinovoi' terapii' [Toxic effects and biochemical control the consequences of anthracycline therapy]. Arhiv Klinichnoi' ta Eksperymental'noi' Medycyny 22(2), 242-248 (in Ukrainian).

Bouchet, S., Bauvois, B., 2014. Neutrophil gelatinase-associated lipocalin (NGAL), pro-matrix metalloproteinase-9 (proMMP-9) and their complex pro-MMP-9/NGAL in leukaemias. Cancers 6, 796-812.

Fu, J., Chen, X., Zhang, Y., Gu, H., Bai, Y., 2010. CD147 and VEGF co-expression predicts prognosis in patients with acute myeloid leukemia. Jpn. J. Clin. Oncol. 40(11), 10461052.

Gajdamaka, N.V., Parovichnikova, E.N., Zavalishina, L.J., Savchenko, V.G., Frank., G.A., 2009. Jekspressija matriksnyh metalloproteinaz $\mathrm{i}$ ih ingibitorov $\mathrm{v}$ kostnom mozge $\mathrm{u}$ bol'nyh ostrymi lejkozami [Expression of matrix metalloproteinases and their inhibitors in the bone marrow of patients with acute leukemia]. Gematologija i Transfuziologija 54(2), 3-10 (in Russian).

Kannaiyan, R., Surana, R., Shin, E.M., Ramachandran, L., Sethi, G., Kumar, A.P., 2012. Targeted inhibition of multiple pro- inflammatory signaling pathways for the prevention and treatment of multiple myeloma. Chapter 5, 93-128.

Klein, G., Vellenga, E., Fraaije, M.W., Kamps, W.A., De Bont, E.S.J.M., 2004. The possible role of matrix metalloproteinase (MMP)-2 and MMP-9 in cancer, e.g. acute leukemia. Crit. Rev. Oncol. Hematol. 50, 87-100.

Mittelstadt, M.L., Pate, R.C., 2012. AP-1 mediated transcriptional repression of matrix metalloproteinase- 9 by recruitment of histone deacetylase 1 in response to interferon $\beta$. PLoS One 7(8), e42152.

Spallarossa, P., Altieri, P., Garibaldi, S., Ghigliotti, G., Barisione, C., Manca, V., Fabbi, P., Ballestrero, A., Brunelli, C., Barsotti, A., 2006. Matrix metalloproteinase-2 and -9 are induced differently by doxorubicin in H9c2 cells: The role of MAP kinases and NAD(P)H oxidase. Cardiovasc. Res. 69, 736-745.

Vadhan-Raj, S., Bueso-Ramos, C.E., Hangoc, G., Christopherson, K., Collard, M., Broxmeyer., H.E., 2005. Expansion of bone marrow progenitors and mobilization of multilineage progenitor cells associated with once-per-cycle administration of the long-acting growth factors pegfilgrastim and darbepoetin alfa with chemotherapy. J. Support. Oncol. 3(2), 22-23.

Van Valckenborgh, E., Asosingh, K., Van Riet, I., Van Camp, B., Vanderkerken K., 2004. Matrix metalloproteinases in multiple myeloma. Cancer Ther. 2, 29-38.

Vygovs'ka, J.I., Karol', J.S., Lukavec'kyj, L.M., Mazurok, A.A., Masljak, Z.V., Matlan, V.L., Novak, V.L., Rudenko, V.P., Cjapka, O.M., 2002. Standarty v gematologii' [Standards in Haematology]. PP Kvart, L'viv (in Ukrainian).

Yu, X.F., Han, Z.C., 2006. Matrix metalloproteinases in bone marrow: Roles of gelatinases in physiological hematopoiesis and hematopoietic malignancies. Histol. Histopathol. 21, 519-531.

Надійшла до редколегії 24.03.2014 